\title{
Bondability of Beech Wood with One-component Polyurethane Structural Adhesive
}

\author{
Norbert HORVÁTH ${ }^{\mathrm{a}^{*}}-$ Csilla CSIHA $^{\mathrm{b}}$ \\ ${ }^{a}$ Institute of Wood Science, University of West Hungary, Sopron, Hungary \\ ${ }^{\mathrm{b}}$ Institute of Wood Products and Technologies, University of West Hungary, Sopron, Hungary
}

\begin{abstract}
The bondability of beech (Fagus sylvatica L.) wood with a one-component polyurethane (1K PUR) structural (load-bearing) adhesive has been investigated at the Simonyi Károly Faculty at the University of West Hungary. Our trial is considered a preliminary investigation in order to set the convenient parameters of bonding for the structural gluing of beech wood. Wood samples were characterized by their oven dry density, and the surfaces to be bonded were characterized by their surface roughness and surface tension after machining. Based on our measurements, we have made a suggestion on the value of the ensemble of open time, applied quantity and pressure, pressing time, and surface preparation/surface roughness parameters which result in good bonding and a shear strength higher than $10 \mathrm{~N} / \mathrm{mm}^{2}$. Furthermore, we investigated the penetration of the adhesive into the surface and state that one-sided adhesive application results in differing levels of penetration. In order to check the suitability of beech wood for glued laminated timber production, further investigations according to EN standards are necessary. Based upon the considerations noted above, delamination tests are already under evaluation.
\end{abstract}

Fagus sylvatica / load-bearing glued laminated timber / bondability / penetration

Kivonat - Bükk faanyag ragaszthatósága egykomponens poliuretán szerkezeti ragasztóval. Bükk (Fagus sylvatica L.) faanyag ragaszthatósági vizsgálatait egykomponens poliuretán (1K PUR) szerkezeti ragasztóval a Nyugat-magyarországi Egyetem Simonyi Károly Karán végeztük. Vizsgálatuk a bükk faanyag szerkezeti ragasztásához megfelel paraméterek beállításához szükséges el zetes kísérletnek tekinthet . A famintákat abszolút száraz s $\mathrm{r}$ séggel a ragasztandó felületeket pedig a felületi érdességgel és felületi feszültséggel jellemeztuik. Méréseink alapján javaslatot tettünk a nyílt id , a felhordott ragasztómennyiség, a présnyomás, a présid a megmunkálás/fafelületi érdesség, a faanyag nedvességtartalom, illetve a felületi feszültség paraméterek együttesének olyan értékére, mely mellett a ragasztás elvégezhet és a ragasztott kötés nyírószilárdsága nagyobb, mint $10 \mathrm{~N} / \mathrm{mm}^{2}$. Vizsgáltuk továbbá a ragasztó penetrációját a faanyagban, és megállapítottuk, hogy különbség van az egyoldalas és a kétoldalas ragasztó felhordás esetén el álló behatolási mélységek között. A bükk faanyag rétegeltragasztott tartók gyártására való alkalmasságához további, az MSZ EN szabvány szerinti vizsgálatok is szükségesek. Ezen megfontolások alapján a rétegelválás (delamináció) vizsgálatok értékelése már folyamatban van.

Fagus sylvatica / rétegelt-ragasztott szerkezeti fa / ragaszthatóság / behatolási mélység

\footnotetext{
* Corresponding author: norbert.horvath@skk.nyme.hu; H-9400 SOPRON, Bajcsy-Zs. u. 4. Hungary
} 


\section{INTRODUCTION}

In Europe, coniferous species are the most commonly used species for glued laminated timber production. Yet according to Wittmann (2000), theoretically, no species can be excluded from the field of structural application. However, economic considerations, structural specificities, and other requirements set some limitations and the use of all species is not justified. Ebener (2001) points out that $60-75 \%$ of German sawn timber production meant for construction purposes are coniferous species, and the proportion of classical construction timber, length jointed timber, and other glued laminated timber reaches 30-50\%. Furthermore, he emphasizes that the need for glued laminated structural timber is increasing.

Numerous tests have been conducted regarding structural gluing of beech wood in order to answer whether the wood material of broadleaved species is suitable for glulam structural element production and what the generally valid gluing parameters of fluent production technology are (Frühwald et al. 2003, Blaß et al. 2005, Frese 2006). Frühwald et al. (2003) tested six layer glulam beams, steaming the beech lamellas before gluing in order to homogenize color deviations originated from redheart and to decrease internal tension existing in the wood material. They found that beech can be a key important raw material for slim structures as it possesses good mechanical properties, but it should be used primarily indoors due to its limited durability.

Besides the use of coniferous species, there is an international trend towards the use of hardwoods for structural purposes; this is supported by intense research activity. Ohnesorge (2009) published comprehensive results on the usability of beech (Fagus sylvatica L.) wood bonded with PUR, MUF, PRF structural adhesives for structural purposes. His investigations targeted both the strength of the bond and the delamination as well. According to his results, when determining the shear strength of the samples prepared according to MSZ EN 14080, the breakage of grains was around $15 \%$ in the case of the PUR adhesive, around $91 \%$ in the case of PRF adhesive, and around $81 \%$ in the case of MUF adhesive. Furthermore, he stated that neither heartwood nor steaming exert a relevant effect on the bondability of MUF adhesives. In addition to this, he pointed out that by choosing a convenient open time and a maximized lamella thickness of $30 \mathrm{~mm}$, good bondline strength can be achieved.

Along with the successful bonding of different hardwood species, delamination behavior is another issue that needs to be considered; thus, several investigations have been conducted in order to increase the bond strength and to decrease the delamination by using surfaceactivating agents (Csiha et al. 2010) or by changing the chemical status of the wood surface by treatments like plasma or laser (Gerstenberg - Viöl 2005). Improvements have also been reported by using hydroxy-methylated resorcinol (HMR polymer) (Vick et al. 1995, Christiansen et al. 2003, Christiansen 2005, Eisenheld - Gardner 2005). Lópes-Suevos and Richter (2009) observed significantly reduced delamination of glue laminated eucalypt timber (Eucalyptus globulus ) when bonded with HMR primer.

\section{MATERIALS AND METHODS}

\subsection{Wood species investigated}

The investigations have been performed in order to gain information regarding the bondability of beech wood with the available 1K PUR structural adhesive. Wood samples have been characterized by their oven dry density and the surfaces to be bonded have been characterized by their surface roughness and surface tension after machining.

Primarily, beech (Fagus sylvatica L.) is a central European wood species, but is also present in Britain and southern Scandinavia between the $40^{\circ}$ and $60^{\circ}$ latitudes. In the north it 
also grows on the low plains, but generally it is considered a wood species of hilly-mountain regions at 600-800 m altitude. In Hungary beech forms coherent stands in Északi-középhegység (the mountains east of the Danube), Magas-Bakony (the highest part of the Bakony), Zala County, Mecsek, Zselicség, K szeg and Sopron Mountains (Molnár - Bariska 2006).

\subsection{Wood samples and adhesive}

A total of 50 lamellas of $15 \mathrm{~mm}$ thickness were prepared by planing from defect free specimens of beech wood. They were conditioned at room temperature $\left(20^{\circ} \mathrm{C}\right.$ air temperature, $60 \%$ relative humidity). The chosen adhesive was the Jowat 686.60 type $1 \mathrm{~K}$ (PUR) adhesive, frequently used by industry for structural bonding of coniferous species (except larch). The lamellas were glued together at one side using $220 \mathrm{~g} / \mathrm{m}^{2}$ of adhesive application, 30-40 minutes open assembly time, $1 \mathrm{~N} / \mathrm{mm}^{2}$ of pressure, and 3 hours of pressing time (closed assembly time of 6-8 $\mathrm{min}$ ).

\subsubsection{Determination of moisture content and density of the samples}

For the measurement of net moisture content (MC) and respective density after conditioning at normal climate, $20 \mathrm{~mm} \times 20 \mathrm{~mm}$ (perpendicular to the grain) and $30 \mathrm{~mm}$ parallel to the grain prism-like samples were prepared. In order to measure their size and weight, a digital caliper and a digital balance were used, both with measuring accuracy down to 0.01 . Drying of samples was performed in a drying chamber at $103 \pm 2{ }^{\circ} \mathrm{C}$ air temperature. The values were calculated by the following formulas ( 1 and 2$)$ :

$$
M C=\frac{m_{x}-m_{o}}{m_{o}} \cdot 100
$$

Where:

$M C$ is the moisture content in \%

$m_{x}$ is the wet mass in $\mathrm{g}$

$m_{o}$ is the oven dry mass in $\mathrm{g}$

$$
\rho_{0}=\frac{m_{0}}{l_{0} \cdot r_{0} \cdot t_{0}} \cdot 10^{6}
$$

Where:

$\rho_{0}$ density of the absolute dry samples, in $\mathrm{kg} / \mathrm{m}^{3}$

$l_{0} \quad$ the size of the absolute dry samples parallel to the grain, in $\mathrm{mm}$

$r_{0}$ the size of the absolute dry sample in radial direction, in $\mathrm{mm}$

$t_{0}$ the size of the absolute dry sample in tangential direction, in $\mathrm{mm}$

$m_{0}$ the weight of the absolute dry sample, in $\mathrm{g}$

\subsubsection{Surface roughness measurement}

The measurements were performed on the planed surface of the samples with $150 \mathrm{~mm} \times 50 \mathrm{~mm} \times 15 \mathrm{~mm}$ dimension. A total of 50 roughness measurements were performed, one on each sample, using a Mahr Perthen SP 3 instrument equipped with a stylus tip of $5 \mathrm{~m}$ radius (Figure 1). The instrument calculates the roughness parameters automatically using a Gaussian filter. 


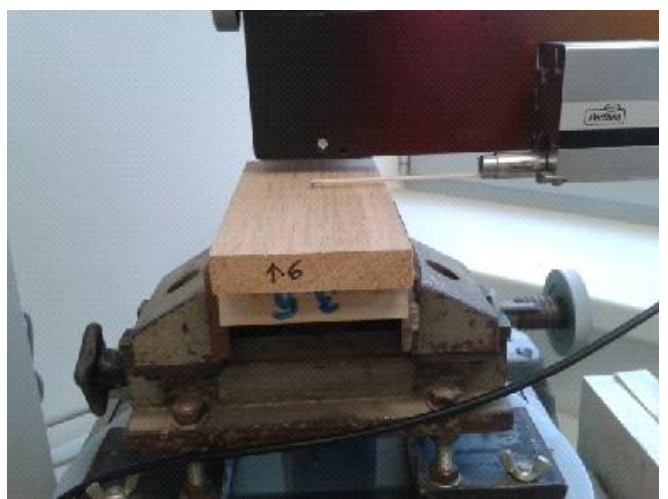

Figure 1. The S3P Perthometer with the stylus tip

The surface roughness profile and the chosen roughness values were printed on thermopaper. For the surface roughness characterization, the $\mathrm{R}_{\mathrm{z}}$ parameters were chosen for evaluation. The stylus detected the surface geometry perpendicular to the grain, along a $17.5 \mathrm{~mm}$ long trace, consisting of 7 of $2.5 \mathrm{~mm}$ long consecutive sampling lengths. $\mathrm{R}_{\mathrm{z}}$ parameters are calculated as mathematical mean of five consecutive $l_{e}$ sampling lengths, not considering the first and the last $l_{\mathrm{e}}$ of the total measured length as shown on Figure 2. Since single extreme profile peaks usually have only a limited influence on the part's performance, $\mathrm{R}_{\mathrm{z}}$ followed by $\mathrm{R}_{\mathrm{a}}$ is the most suitable surface parameter for the characterization of diffuse porous wood species with relative homogeneous structure (Perez et al. 2012). $R_{z}$ followed by $R_{a}$ (average roughness) and $R_{\max }$ (the maximal roughness) are suitable to describe the status of the surface (Magoss - Tatai 2009).

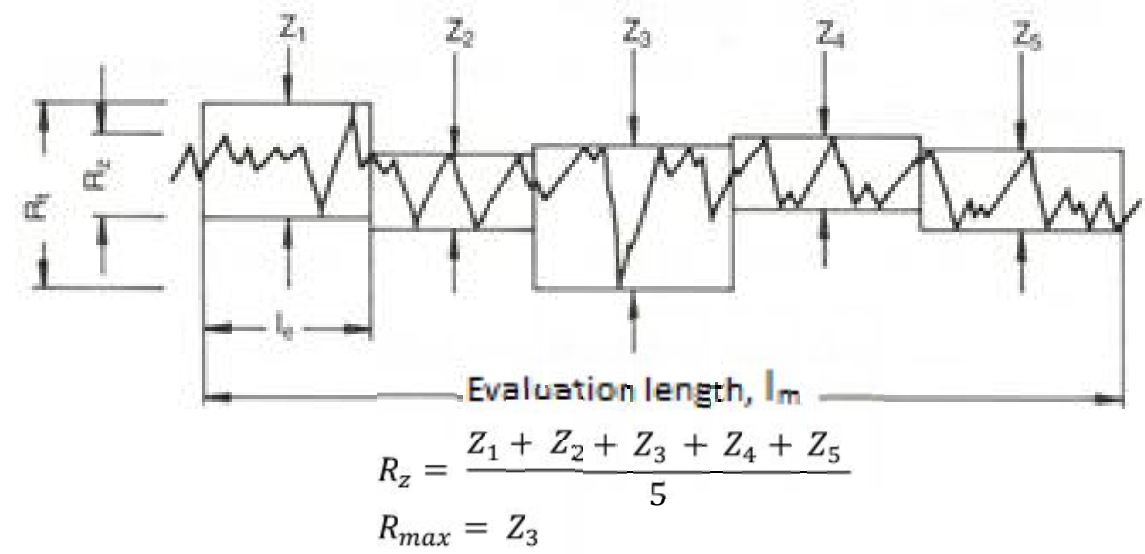

Figure 2. The calculation of the $R_{z}$ parameter along the evaluation length (Csiha - Krisch 2000)

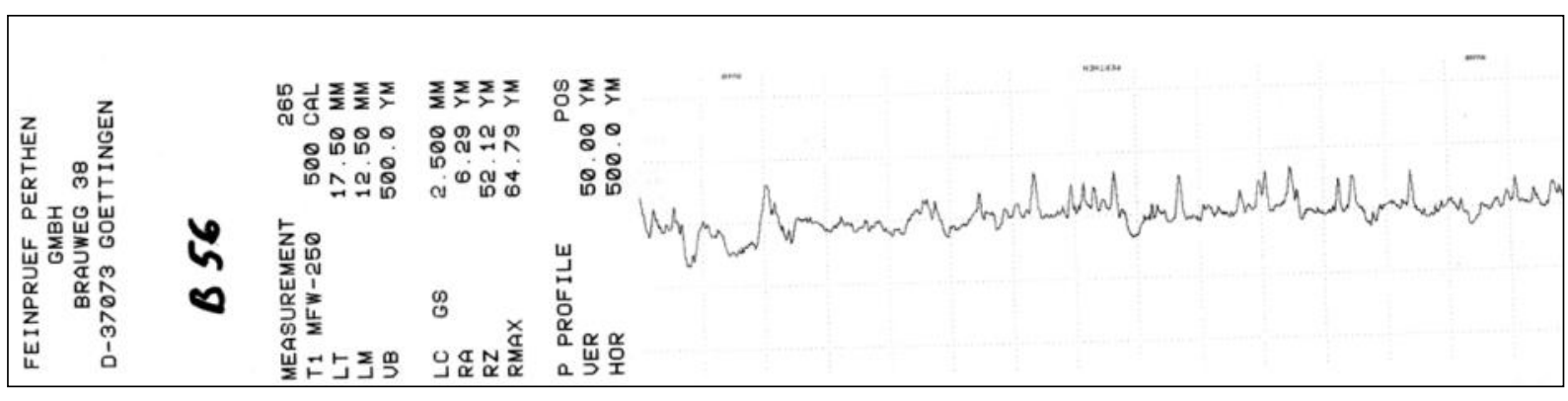

Figure 3. A roughness profile on thermo-paper 


\subsubsection{Surface tension measurement}

Surface tension was measured by means of a PGX Goniometer, taking 10 measurements on each sample type. During the measurements, a drop of liquid was placed on the surface of wood sample. It was assumed that the liquid does not react with the solid. It was emphasized that contrary to ideal smooth surfaces, the drop of water is distorted along the grains, taking a form of a semi oval sphere. The volume of the measuring drop was of $0.4 \mu \mathrm{l}$, and the contact angle was automatically detected and measured at $1 \mathrm{sec}$ after the release of the droplet, as previously agreed. Distilled water was used as the test liquid. The measuring instrument was calibrated before each measurement. The contact angle was measured as the angle between the outline tangent of the smaller diameter and surface. The surface free energy was automatically calculated by the computer equipped Goniometer.

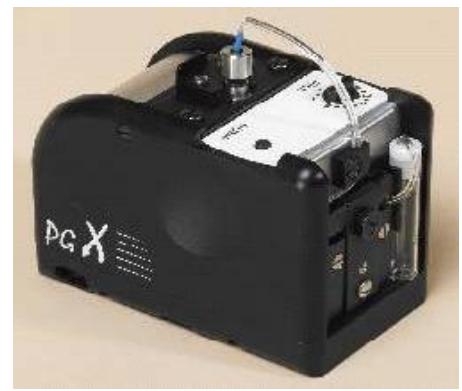

Figure 4. A PGX goniometer for surface tension measurement

\subsection{Pressing of samples}

The application of the adhesive and pressing of samples were performed in the workshop of the UWH, Simonyi Károly Faculty of Engineering, Wood Science and Arts. The adhesive was applied at room temperature at $65 \%$ relative humidity. The chosen amount of adhesive according to the technical datasheet was $220 \mathrm{~g} / \mathrm{m}^{2}$. It was applied on one side with a roller within an open time of 30-40 min. A total of 24 samples were prepared using a Stromab STH hydraulic press (Figure 5) in one step pressing, by stacking the samples. The pressing load was $1.0 \mathrm{~N} / \mathrm{mm}^{2}$, with a pressing time of 3 hours.

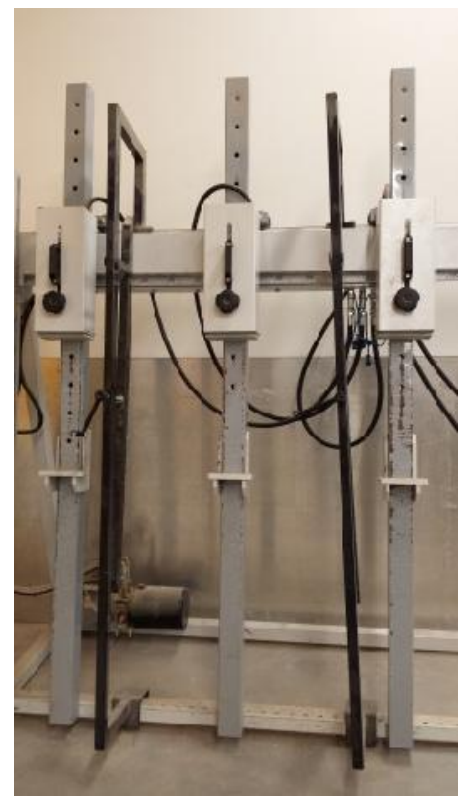

Figure 5. The Stromab STH press 


\subsection{Determination of the bond strength}

Samples suitable for shear strength measurement were prepared according to MSZ EN 302-1 (Figure 6). The samples were acclimatized according to MSZ EN 302-1 for 7 days at room temperature $\left(20^{\circ} \mathrm{C}\right.$ temperature and $65 \%$ relative humidity) and tested afterwards. The shear strength was determined by using a TiniusOlsen H10K type instrument (Figure 7). The area that was supposed to shear on each sample was measured by digital calliper. The shear strength of the 24 samples was calculated using the following equation:

$$
\tau=\frac{F_{\max }}{A}\left[\mathrm{~N} / \mathrm{mm}^{2}\right]
$$

Where:

$F_{\text {max }}$ the maximal force, in $\mathrm{N}$

$A \quad$ the area of the exposed portion, in $\mathrm{mm}^{2}$

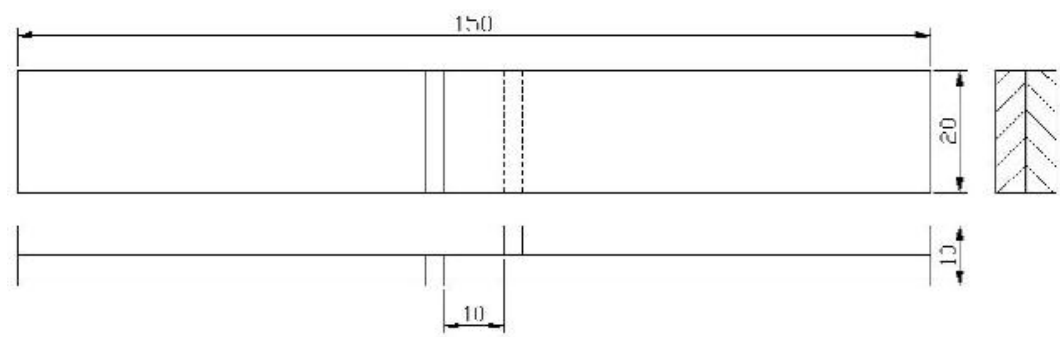

Figure 6. Sample for shear strength measurement according to MSZ EN 302-1

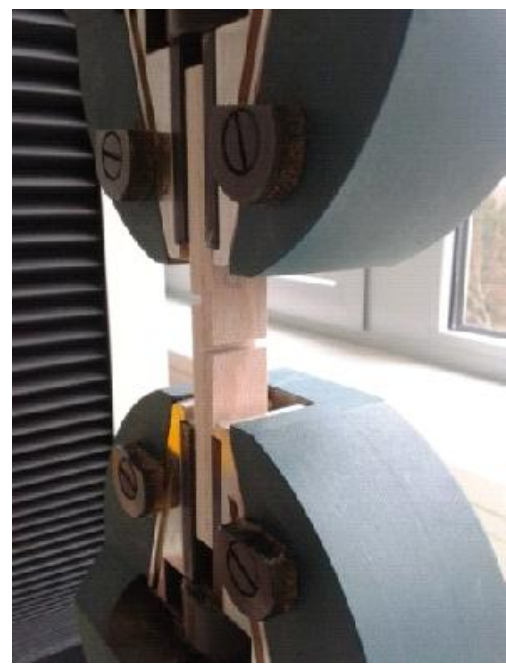

Figure 7. TiniusOlsen H1OK instrument with a sample

\subsection{Determination of adhesive penetration}

For the determination of adhesive penetration, a Nikon SMZ800 microscope was used (Figure 8). Samples that were $10 \mathrm{~mm}$ thick were cut perpendicularly to the grain as the falling end from the glued samples right after the stock was taken out of the press. During the investigation, microscope images were taken from the butt end of the glued samples, and thus from the glueline aided by an Image Pro software. 


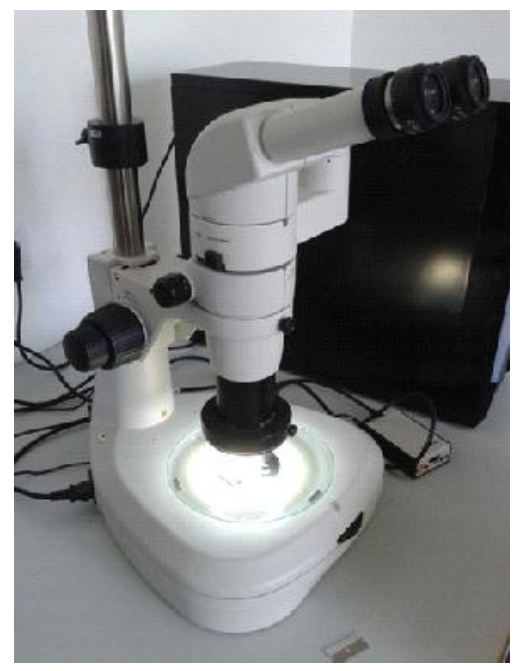

Figure 8. Nikon SMZ800 microscope

\section{RESULTS AND DISCUSSION}

The investigations were performed in order to gain information regarding the bondability of beech wood with the available 1K PUR structural adhesive as the chosen adhesive (Jowat 686.60 type $1 \mathrm{~K}$ (PUR)) is frequently used by industry for structural bonding of coniferous species (except larch). The thickness of the glueline was around $0.3 \mathrm{~mm}$, lower than the maximum suggested by the adhesive manufacturer. The average density of the samples was $735 \mathrm{~kg} / \mathrm{m}^{3}$, which is typical for beech wood. The average MC of the samples was $9.22 \%$. There were some samples with MC around 8-9\%, but later on they did not show any difference in their shear strength suggesting that the reaction of the PUR adhesive was performed without any obstacle in their case also. The pressing load used was $1.0 \mathrm{~N} / \mathrm{mm}^{2}$, while the pressing time was 3 hours. The shear strength of the bond and the penetration of the adhesive were determined. In each shear test, the wood broke, meaning that the adhesive bond was stronger than the cohesion of the beech wood material.

\subsection{Results of surface roughness and surface tension}

The surface roughness of the planed beech surfaces was influenced both by machining - planing in this case - and the tissue structure of the wood. The average surface roughness of the samples is given in Table 1 .

Table 1. Contact angle, surface tension and surface roughness $\left(R_{a}, R_{z}, R_{\max }\right)$ of planed beech samples

\begin{tabular}{lccccc}
\hline & $\begin{array}{c}\text { Contact angle } \\
\left({ }^{\circ}\right)\end{array}$ & $\begin{array}{c}\text { Surface } \\
\text { tension }(\mathrm{N} / \mathrm{m})\end{array}$ & $\begin{array}{c}\mathrm{R}_{\mathrm{a}} \\
(\mu \mathrm{m})\end{array}$ & $\begin{array}{c}\mathrm{R}_{\mathrm{z}} \\
(\mu \mathrm{m})\end{array}$ & $\begin{array}{c}\mathrm{R}_{\max } \\
(\mu \mathrm{m})\end{array}$ \\
\hline Average & 72.73 & 38.8 & 6.52 & 50.45 & 67.31 \\
st. dev. & 20.79 & 7.61 & 1.43 & 8.7 & 17.05 \\
\hline
\end{tabular}




\subsection{Results of bond strength}

Samples were subjected to pulling and thus shear stress was induced. In each case the wood broke, meaning that the adhesive bonding was stronger than the cohesion of the beech wood material. The values of the shear strength are as per Table 2 .

Table 2. The shear strength of the samples (parallel to the grain)

\begin{tabular}{lcccc}
\hline & Average & St. dev. & Min & Max \\
\hline Shear strength $\left(\mathrm{N} / \mathrm{mm}^{2}\right)$ & 16.79 & 4.05 & 11.08 & 29.38 \\
\hline
\end{tabular}

\subsection{Results on adhesive penetration}

According to the images taken, the adhesive penetrated twice as deep with direct application $(334.23 \mathrm{~m})$ than it did with indirect adhesive application. (Table 3) The thickness of the glueline was around $280 \mathrm{~m}$, lower than the maximum suggested by the adhesive manufacturer.

Table 3. Adhesive penetration

\begin{tabular}{lcccc}
\hline & Average & St. dev. & Min & Max \\
\hline Direct adhesive application $(\mathrm{m})$ & 334.23 & 154.28 & 97.14 & 647.60 \\
Indirect adhesive application $(\mathrm{m})$ & 149.19 & 63.89 & 45.33 & 304.40 \\
\hline
\end{tabular}

\section{CONCLUSIONS}

Surface roughness and surface tension measurements were also performed. The average surface roughness of the samples was: $\left.\left(R_{a}\right) 6.52 \mu \mathrm{m}, R_{z}\right) 50.45 \mu \mathrm{m}$ and $\left(R_{\max }\right) 67.31 \mu \mathrm{m}$ associated with an average surface tension of $38.80 \mathrm{~N} / \mathrm{m}$. The samples possessing the above characteristics were glued together with a Jowat 686.60 1K PUR structural adhesive The average value of the shear strength was $16.79 \mathrm{~N} / \mathrm{mm}^{2}$, while the lowest value was $11.08 \mathrm{~N} / \mathrm{mm}^{2}$ (Table 2).

According to the results, the strength of the adhesive suits level A1 (EN 301). As evidenced in the images taken, the adhesive penetrated twice as deep on the side of direct application $(334.23 \mathrm{~m})$ than it did on the side of indirect adhesive application (Table 3). Although the shear test results were satisfactory, the information is relevant for future investigations regarding the measurement of shear strength in light of adhesive penetration.

Based on the above mentioned results, one can state that planed beech surfaces that have $9.22 \%$ average $\mathrm{MC}, 735 \mathrm{~kg} / \mathrm{m}^{3}$ average density, average roughness of $\mathrm{R}_{\mathrm{z}}=50.45 \mu \mathrm{m}$, surface tension of $38.80 \mathrm{~N} / \mathrm{m}$ with Jowat 686.60 type $1 \mathrm{~K}$ (PUR) adhesive of $220 \mathrm{~g} / \mathrm{m}^{2}$ quantity applied to one side, open time of 30-40 min, closed time of 6-8 $\mathrm{min}$, and pressing time of 3 hours, that bonding can be performed without obstacles. Also, at dry strength a higher value than $11 \mathrm{~N} / \mathrm{mm}^{2}$ can be expected.

Acknowledgements: The authors are grateful to Kálmán Kránicz for the technical assistance provided in the measurements. 


\section{REFERENCES}

Blaß, H. J. - Denzler, J. - Frese, M. - Glos P. - Linsemann, P. (2005): Biegefestigkeit von Brettsichtholz aus Buche - Karlsruher Berichte zum Ingenieurholzbau. Universität Karlsruhe, Universitätsverlag Karlsruhe

CSIHA Cs. - KRISCH J. (2000): Vessel filtration - a method for analisyng wood surface roughness of large porous species. Drevasky Vyskum 45: (1) 13-22.

CsIHA CS. - CsóKA L. - LiTRESITS G. - BICZÓ G. (2010): LbL treatment of wood surfaces in order to improve bondline performance. In: Processing Technologies for the Forest and Biobased Products Industries. Salzburg, Austria. 48-49.

Christiansen, A.W. - Vick, C.B. - OKKonen, E. (2003): Development of a novalak-based hydroxymethylated resorcinol coupling agent for wood adhesives. Forest Prod. J. 53 (2):32-38.

CHRISTIANSEN, A. W. (2005): Chemical and mechanical aspect of HMR primer in relationship to wood bonding. Forest Prod. J. 55 (11):73-78;

EBENER, G. (2001): BSH - Kapazitätsbau - Mittelfristig eine Million mehr am Markt. Holzkurier Sonderheft 856:11 p.

EISENHELD, L. - GARDNER, D.J. (2005): Developing an industrial friendly process for hydroxymethyl resorcinol (HMR) priming of wood using a novolak-based HMR. Forest Prod. J. 55 (9): 61-66.

FRESE, M. (2006): Die Biegefestigkeit von Brettschichtholz aus Buche experimentelle und numerische Untersuchungen zum Laminierungseffekt. Universitätsverlag Karlsruhe

FRÜHWALD, A. - RESSEL, J.B. - BERNASCONI, A. (2003): Hochwertiges Brettschichtholz aus Buchenholz. Abschlussbericht. Institut für Holzphysik und mechanische Technologie des Holzes, Bundesforschungsanstalt für Forst- und Holzwirtschaft, Hamburg

GERSTENBERG, K. - ViöL, W. (2005): Plasma-Behandlung von Holzoberflächen - Umsetzung in die Industrielle Praxis. Vortrag, Symposium „Holz Innovativ“ 2005.04.07. Kultur- und Kongresszentrum Rosenheim

LÓPES-SUEVOS, F. - RICHTER, K. (2009): Hydroxymethylated resorcinol (HMR) and novolak-based HMR (n-HMR) primers to enhance bond durability of Eucalyptus globulus glulams. J. Adhes. Sci. Technol 23 (15):1925-1937

MAGOSS, E. - TATAI, S. (2009): Surface roughness of natural wood - rality versus measured figures. In: Proceedings of the $20^{\text {th }}$ International Wood Machining Seminar. Skelleftea, Sweden.

MOLNÁR, S. - BARISKA, M.(2006): Magyarország ipari fái. [Wood Species of Hungary] Szaktudás Kiadó Ház, Budapest. p. 70-82. ISBN: 9639422533

MSZ EN 301 (2006): Classification and performance requirements

MSZ EN 302-1 (2004): Adhesives for load-bearing timber structures - Test methods - Part 1: Determination of longitudinal tensile shear strength

MSZ EN14080 (2013): Timber structures. Glued laminated timber and glued solid timber. Requirements

OHNESORGE, D. (2009): Verklebungseigenschaften von Brettschichtholz aus Buchenholz (Fagus sylvatica L.), Fakultät für Forst- und Umweltwissenschaften der Universität Freiburg, und Forstliche Versuchs- und Forschungsanstalt Baden-Württemberg, ISBN 978-3-933548-44-3

PereZ A.G. - SAlCĂ, E.A. - MALdONADO, I.B. - HizIROGLU, S. (2012): Evaluation of surface quality of medium density fiberboards (MDF) and particleboards as function of weathering. Pro Ligno Journal 8: 10-17.

VICK, C.B. - RICHTER, K. - RIVER, B.H. -FRIED, A.R. (1995): Hydroxymethylated resorcinol coupling agent for enhanced durability of bisphenol-A-epoxi donds. Wood Fiber Sci. 27 (1): 2-12.

WitTMANN, Gy. (2000): Mérnöki szerkezetek I. [Engineering structures I.] Mez gazdasági Szaktudás Kiadó, Budapest. p. 115; 310; 330-339; ISBN: 9633563143 
